\title{
A Meta-Analysis on the Elasticity of Demand for Pesticides
}

\section{Journal Article}

Author(s):

Böcker, Thomas G.; Finger, Robert (I)

Publication date:

2017-06

Permanent link:

https://doi.org/10.3929/ethz-b-000122189

Rights / license:

In Copyright - Non-Commercial Use Permitted

Originally published in:

Journal of Agricultural Economics 68(2), https://doi.org/10.1111/1477-9552.12198 


\section{Postprint}

This is the accepted version of a paper published in Ecological Economics.

\section{Citation for the original published paper:}

Böcker, T. and Finger, R. (2017). A Meta-Analysis on the Elasticity of Demand for Pesticides. Journal of Agricultural Economics Vol. 68 (2): 518-533. https://doi.org/10.1111/1477-9552.12198

Access to the published version may require subscription.

N.B. When citing this work, cite the original published paper 


\title{
A Meta-Analysis on the Elasticity of Demand for Pesticides
}

\author{
Thomas Böcker ${ }^{a}$ and Robert Finger ${ }^{b}$
}

a Institute for Food and Resource Economics, Rheinische Friedrich-Wilhelms-

Universität Bonn, Germany. Contact: t.boecker@ilr.uni-bonn.de

b Agricultural Economics and Policy Group, ETH Zürich, Switzerland.

Contact: rofinger@ethz.ch

\begin{abstract}
There is an increasing policy interest in pesticide taxation schemes as a measure to reduce harmful effects of pesticide use. The effectiveness of such tax depends, however, on the price elasticity of demand for pesticides. Moreover, information on these demand elasticities and their determinants is of crucial relevance for policymaking and normative modeling approaches. In this article, we present a meta-analysis based on studies that have estimated pesticide demand elasticities in Europe and North America. Our metaanalysis reveals that the own-price elasticities of demand for pesticides are, with a median of -0.28 , significantly smaller than zero, but also significantly larger than -1 , i.e. to be inelastic. We find that the demand for pesticides for special crops is less elastic than that for arable and grassland. In addition, the demand for herbicides is more elastic than for other pesticides. Studies that consider only short-term horizons and little flexibility for farmers to adjust to price changes generate significantly less elastic pesticide demands. The results also indicate that more recent studies identify lower pesticide price elasticities of demand. Furthermore, we find that peer-reviewed studies tend to find more inelastic results compared to grey literature.
\end{abstract}

Keywords: Agricultural policy; demand analysis; meta-analysis; own-price elasticity of demand; pesticide tax; pesticides; robust regression. 


\section{Introduction}

Reductions of harmful effects of pesticide use are high on agricultural policy agendas. For instance, national action plans have been established in countries of the European Union and pesticide taxation schemes have been established in some European countries (i.e. France, Sweden, Norway, Denmark) (Böcker and Finger, 2016; Lefebvre et al., 2015). There have also been recent discussions on an introduction of a taxation scheme in other European countries such as Belgium, the Netherlands and Germany (ARCADIS Belgium, 2014; Hof et al., 2013; Möckel et al., 2015a,b). The effectiveness of such taxes depends on the demand response of farmers to higher pesticide prices. More specifically, low own-price elasticities of demand have been claimed to be a major hurdle for effective regulation of pesticide use via taxes (e.g. Falconer and Hodge, 2000; Fernandez-Cornejo et al., 1998). Overviews of estimates of pesticide demand elasticities in developed countries have been provided in studies by Capalbo and Vo (1988), Falconer and Hodge (2000), Fernandez-Cornejo et al. (1998) and Hoevenagel et al. (1999). These overviews are cited frequently and serve as important references for assumptions made in normative modeling approaches (e.g. Möckel et al., 2015a) and for comparison with positive studies (e.g. Muñoz Piña and Avila Forcada, 2004; Skevas et al., 2012).

Despite the importance of these overviews for policy analysis and policy recommendations, there are several shortcomings and unexplored potentials. Most obviously, the existing overviews on pesticide demand elasticities are now outdated - the most recent being 2000. ${ }^{1}$ Further limitations result from the fact that no comprehensive statistical meta-analyses on pesticide demand elasticities have been conducted. ${ }^{2}$ Specifically, no distinction between short- and long-term elasticities has been made that accounts for farmers' flexibility to adjust to price changes, especially over longer time horizons. However, this distinction reflects crucial information for normative policy analysis of the effects of pesticide taxation (e.g. Möckel et al., 2015a). Moreover, there has been no systematic analysis of differences of pesticide demand elasticities across

\footnotetext{
${ }^{1}$ More recently, Skevas et al. (2013) presented an overview based on Fernandez-Cornejo et al. (1998), Hoevenagel et al. (1999) and Falconer and Hodge (2000), without adding further studies beyond 1997.

${ }^{2}$ The study by Bergh et al. (1997) presents a structured meta-analysis of some studies on pesticide demand elasticities, not covering the addressed points here empirically.
} 
different agricultural systems and types of pesticides. In addition, no distinction between methodological approaches underlying demand elasticity estimates has been considered, despite the fact that a large variety of methodological approaches has been used to derive elasticities (e.g. econometric vs. optimisation models). Finally, no distinction between peer-reviewed and grey literature has been made. In this note, we aim to fill these gaps and provide a meta-analysis on pesticide demand elasticities. We focus on results from developed countries of the northern hemisphere to include estimates from comparable agricultural systems.

\section{Methodology and Data}

To identify relevant studies, we used bibliographic databases such as Scopus and Google Scholar, and the key words 'pesticide', 'pesticide tax/levy/charge' together with 'elasticity' (singular and plural). In total, 31 studies were identified that report original pesticide demand elasticities. We provide detailed argumentation on the inclusion and exclusion of studies in Appendix A.

From the selected studies, we obtained the following information, as available: (i) the year of publication, (ii) the period of analysis/data collection period, (iii) the country/ region that was the subject of the analysis, (iv) the cropping system investigated, with classification into arable and grassland farming, special crops (horticulture, fruit production, viticulture), and an aggregate bundle when no specific production type was analysed, (v) the type of pesticide investigated, i.e. herbicides, fungicides, insecticides and pesticides in general, (vi) the considered flexibility/time span, i.e. short-term/fix or long-term/variable, ${ }^{3}$ (vii) the estimated demand elasticity for pesticides, (viii) min-max values of these demand elasticity estimates, (ix) the method used, with distinction between econometric and normative models, ${ }^{4}$ and (x) information on whether the study was peer-reviewed. Note that publications can be listed multiple times if they present

\footnotetext{
${ }^{3}$ If time span and flexibility are not explicitly defined (self-declared) in the studies, the flexibility of variable inputs serves as a measure for long-term and short-term production. Therefore, longer periods of analysis or data collection periods can cover a short-term horizon if the variables in the models are assumed to be fixed.

${ }^{4}$ Normative approaches comprise mainly optimisation models such as linear programming approaches (profit maximisation or cost minimisation).
} 
demand elasticities, for example, for different regions, agricultural systems, types of pesticides and/or use different methodologies.

We use a non-parametric Wilcoxon-Mann-Whitney test to identify differences across categories, i.e. differences between the size of the price elasticities. More precisely, we test if pesticide demand elasticities (i) are different from zero, (ii) differ across regions (Europe and North America), (iii) differ between long- and short-term horizons considered, (iv) differ across agricultural systems (arable and grassland, special crops and an aggregated sector), (v) differ between peer-reviewed and grey publications, and (vi) differ across methodological approaches (comparing econometric and normative models).

We conduct a multiple linear regression analysis to assess the most important determinants of pesticide demand elasticity estimates $(\eta)$ and to estimate marginal effects:

$\eta(y, L, S, H, E, P, M)=\beta_{0}+\beta_{1} y+\beta_{2} L+\beta_{3} S+\beta_{4} H+\beta_{5} E+\beta_{6} P+\beta_{7} M+\varepsilon$

Specifically, we consider the following variables as potential determinants of the estimates: the middle year of the analysis or data collection period with the base year being defined as $1900(y) .^{5}$ We include dummy variables for long-term horizon considered $(L)$, special crops (as agricultural systems with particularly high pesticide use levels) $(S)$, focus on herbicides $(H)$, European study $(E)$, peer-reviewed publication $(P)$, and the type of methodology (using a dummy for econometric analysis) $(M), b 0, \ldots, b 7$ are the regression parameters that need to be estimated and e represents the error term. Due to the considerable number of outlying observations in our study (see Fig. 1), we use MM-regression, a robust regression technique. ${ }^{6}$ To account for the fact that some studies report more than one observation for some variables, cluster-adjusted variancecovariance matrices are used to derive standard errors. If a study reported a range or an interval for the same measure, mean values are used in both the regression analysis and

\footnotetext{
${ }^{5}$ In addition, we also employed the year of publication, which produced similar results.

${ }^{6}$ The MM-estimator combines a high breakdown point S-estimator and an efficient M-estimator to obtain a high robustness (avoiding biases in coefficient estimates) against outlying observations by maintaining a high level of efficiency (i.e. maintaining low standard errors) (see, for example, Finger, 2010). The interpretation of coefficient estimates remains similar to a standard OLS regression.
} 
the Wilcoxon-Mann-Whitney test, to avoid double counting (Table 1). All statistical analyses are conducted with R (R Core Team, 2015). 
Table 1. Studies with pesticide demand elasticities

\begin{tabular}{|c|c|c|c|c|}
\hline Author (publication year) & Land/region & $\begin{array}{l}\text { Pesticide type (general or: } \\
\text { f/fungicide, h/herbicide, } \\
\text { i/insecticide (if appl. min. to } \\
\text { max.) }\end{array}$ & $\begin{array}{l}\text { Flexibility } \\
\text { (long-term/ } \\
\text { variable, } \\
\text { short-term/fix) }\end{array}$ & $\begin{array}{l}\text { Period of analysis/ } \\
\text { data collection }\end{array}$ \\
\hline Brown and Christensen (1981) & USA & $-0.19(-0.20$ to -0.19$)$ & Long-term & $1947-1974$ \\
\hline Schulte (1983) & Germany/Rhineland & f: $-0.32(-0.45$ to -0.19$)$ & Short-term & 1978-1980 \\
\hline Schulte (1983) & Germany/Rhineland & f: $-0.32(-0.45$ to -0.19$)$ & Long-term & 1978-1980 \\
\hline Schulte (1983) & Germany/Bavaria & f: $-0.17(-0.33$ to 0.00$)$ & Short-term & $1978-1980$ \\
\hline Schulte (1983) & Germany/Bavaria & f: $-0.50(-0.67$ to -0.33$)$ & Long-term & $1978-1980$ \\
\hline Schulte (1983) & Germany/Schleswig-Holstein & f: $-0.21(-0.27$ to -0.14$)$ & Short-term & $1978-1980$ \\
\hline Schulte (1983) & Germany/Schleswig-Holstein & f: $-0.53(-0.80$ to -0.25$)$ & Long-term & $1978-1980$ \\
\hline Schulte (1983) & Germany/South Oldenburg & f: $-0.32(-0.44$ to -0.20$)$ & Short-term & $1978-1980$ \\
\hline Schulte (1983) & Germany/Hessen & f: $-0.63(-0.76$ to -0.50$)$ & Long-term & $1978-1980$ \\
\hline Antle (1984) & USA & -0.19 & Long-term & 1910-1946 \\
\hline Antle (1984) & USA & -0.25 & Long-term & $1947-1978$ \\
\hline Dubgaard (1987) & Denmark & -0.30 & Long-term & 1971-1985 \\
\hline Dubgaard $(1987,1991)$ & Denmark & h: -0.69 & Long-term & 1971-1985 \\
\hline Capalbo (1988) & USA & -0.19 & Long-term & 1948-1983 \\
\hline Capalbo (1988) & USA & -0.88 & Long-term & $1948-1983$ \\
\hline Capalbo (1988) & USA & -0.41 & Long-term & 1948-1983 \\
\hline Capalbo (1988) & USA & -0.47 & Long-term & $1948-1983$ \\
\hline Capalbo (1988) & USA & -0.61 & Long-term & 1948-1983 \\
\hline Capalbo (1988) & USA & -0.70 & Long-term & 1948-1983 \\
\hline Elhorst (1990) & Netherlands & -0.29 & Short-term & 1980-1986 \\
\hline Aaltink (1992), Master's thesis, cit. from Oskam et al. (1992) & Netherlands & $-0.13(-0.23$ to -0.03$)$ & Short-term & unknown \\
\hline Aaltink (1992), Master's thesis, cit. from Oskam et al. (1992) & Netherlands & $-0.39(-0.55$ to -0.23$)$ & Long-term & unknown \\
\hline Aaltink (1992), Master's thesis, cit. from Oskam et al. (1992) & Netherlands & $-0.39(-0.55$ to -0.23$)$ & Long-term & unknown \\
\hline McIntosh and Williams (1992) & USA/Georgia & -0.11 & Long-term & 1950-1986 \\
\hline Oskam et al. (1992) & Netherlands & -0.21 & Short-term & 1970-1988 \\
\hline Oskam et al. (1992) & Netherlands & -0.22 & Medium-term & 1970-1988 \\
\hline
\end{tabular}


Table 1. (continued)

\begin{tabular}{|c|c|c|c|c|}
\hline Author (publication year) & Land/region & $\begin{array}{l}\text { Pesticide type (general or: } \\
\text { f/fungicide, h/herbicide, } \\
\text { i/insecticide (if appl. min. to } \\
\text { max.) }\end{array}$ & $\begin{array}{l}\text { Flexibility } \\
\text { (long-term/ } \\
\text { variable, } \\
\text { short-term/fix) }\end{array}$ & $\begin{array}{l}\text { Period of analysis/ } \\
\text { data collection }\end{array}$ \\
\hline Oskam et al. (1992) & Netherlands & -0.22 & Long-term & $1970-1988$ \\
\hline Oskam et al. (1992) & Netherlands & -0.25 & Short-term & 1970-1988 \\
\hline Oskam et al. (1992) & Netherlands & -0.26 & Medium-term & 1970-1988 \\
\hline Oskam et al. (1992) & Netherlands & -0.29 & Long-term & 1970-1988 \\
\hline Rude (1992) & Denmark & $-0.20(-0.22$ to -0.17$)$ & Short-term & 1987-2004 \\
\hline Rude (1992) & Denmark & $-0.24(-0.27$ to -0.20$)$ & Medium-term & 1987-2004 \\
\hline Rude (1992) & Denmark & $-0.28(-0.32$ to -0.23$)$ & Long-term & $1987-2004$ \\
\hline Villezca-Becerra and Shumway (1992) & USA/California & -0.09 & Long-term & 1951-1982 \\
\hline Villezca-Becerra and Shumway (1992) & USA/Florida & -0.17 & Long-term & 1951-1982 \\
\hline Villezca-Becerra and Shumway (1992) & USA/Iowa & -0.04 & Long-term & 1951-1982 \\
\hline Villezca-Becerra and Shumway (1992) & USA/Texas & -0.21 & Long-term & 1951-1982 \\
\hline Fernandez-Comejo (1993) & USA/Illinois & -0.10 & Short-term & 1949-1982 \\
\hline Fernandez-Comejo (1993) & USA/Illinois & -0.10 & Short-term & 1949-1982 \\
\hline Fernandez-Comejo (1993) & USA/Illinois & -0.12 & Long-term & 1949-1982 \\
\hline Fernandez-Comejo (1993) & USA/Illinois & -0.38 & Long-term & 1949-1982 \\
\hline Fernandez-Comejo (1993) & USA/Indiana & -0.08 & Short-term & 1949-1982 \\
\hline Fernandez-Comejo (1993) & USA/Indiana & -0.08 & Short-term & 1949-1982 \\
\hline Fernandez-Comejo (1993) & USA/Indiana & -0.09 & Long-term & 1949-1982 \\
\hline Fernandez-Comejo (1993) & USA/Indiana & -0.60 & Long-term & 1949-1982 \\
\hline Chambers and Lichtenberg (1994) & USA & -1.53 & Long-term & 1949-1990 \\
\hline Chambers and Lichtenberg (1994) & USA & -1.50 & Long-term & 1949-1990 \\
\hline Chambers and Lichtenberg (1994) & USA & 0.05 & Long-term & 1949-1990 \\
\hline Chen et al. (1994) & USA/Alabama & -2.42 & Long-term & 1949-1986 \\
\hline Gren (1994a) & Sweden & h: -0.97 & Long-term & 1950-1989 \\
\hline Gren (1994b) & Sweden & h: -0.93 & Long-term & 1948-1989 \\
\hline Oude Lansink (1994) & Netherlands & -0.12 & Short-term & $1970-1988$ \\
\hline
\end{tabular}


Table 1. (continued)

\begin{tabular}{|c|c|c|c|c|}
\hline Author (publication year) & Land/region & $\begin{array}{l}\text { Pesticide type (general or: } \\
\text { f/fungicide, h/herbicide, } \\
\text { i/insecticide (if appl. min. to } \\
\text { max.) }\end{array}$ & $\begin{array}{l}\text { Flexibility } \\
\text { (long-term/ } \\
\text { variable, } \\
\text { short-term/fix) }\end{array}$ & $\begin{array}{l}\text { Period of analysis/ } \\
\text { data collection }\end{array}$ \\
\hline Papanagiotou et al. (1994) & Greece & -0.28 & Short-term & $1961-1990$ \\
\hline Papanagiotou et al. (1994) & Greece & -0.28 & Short-term & $1961-1990$ \\
\hline Shumway and Chesser (1994) & USA/Texas & h: $-0.70(-2.00$ to +0.60$)$ & Long-term & 1972-1986 \\
\hline Bauer et al. (1997) & Germany/Hessen & $\mathrm{f}:-0.02$ & Short-term & 1991-1993 \\
\hline Carpentier and Weaver (1997) & France/Ile-de-France, Centre, & $-1.55(-1.97$ to -1.13 & Long-term & 1987-1990 \\
\hline Falconer (1997), Dissertation cit. from Falconer (1998) & UK/East Anglia & $-0.20(-0.30$ to -0.10$)$ & unknown & unknown \\
\hline Komen et al. (1997) & Netherlands & -0.14 & Short-term & 1990 \\
\hline Komen et al. (1997) & Netherlands & -0.11 & Short-term & 1990 \\
\hline Komen et al. (1997) & Netherlands & -0.25 & Long-term & 1990 \\
\hline Oude Lansink and Peerlings (1997) & Netherlands & -0.48 & Long-term & 1970-1992 \\
\hline Russell et al. (1997) & UK/North West & $-1.11(-1.12$ to -1.09$)$ & Short-term & 1989-1993 \\
\hline Jacquet et al. (2011) & France & $-0.77(-1.25$ to -0.28$)$ & Combined & 2002-2007 \\
\hline Ivanova et al. (2012) & Bulgaria & $-0.11(-0.12$ to -0.09$)$ & Long-term & 2002-2008 \\
\hline Ivanova et al. (2012) & Bulgaria & $-0.16(-0.19$ to -0.12$)$ & Long-term & 2002-2008 \\
\hline Ivanova et al. (2012) & Portugal & $-0.19(-0.22$ to -0.16$)$ & Long-term & 2002-2008 \\
\hline Ivanova et al. (2012) & Portugal & $-0.20(-0.23$ to -0.16$)$ & Long-term & 2002-2008 \\
\hline Skevas et al. (2012) & Netherlands & $-0.02(-0.03$ to -0.0003$)$ & Short-term & 2003-2004 \\
\hline Fadhuile et al. (2015) & France & h: -0.63 & Long-term & 2001 \\
\hline Fadhuile et al. (2015) & France & h: -0.68 & Long-term & 2006 \\
\hline Femenia and Letort (2016) & France/Meuse & $-0.17(-0.24$ to -0.10$)$ & Long-term & 2007-2012 \\
\hline
\end{tabular}




\section{Results}

Table 1 lists the studies that are included in the meta-analysis and some selected variables. Note that the tables with the complete information collected, as well as the codes for statistical analyses, are available in Appendices B to C. Fig. 1 presents the elasticities across all studies by the publication year of the studies and type of pesticides considered.

The median elasticity across all studies is -0.28 . Using the Wilcoxon-Mann-Whitney test, we can reject the null-hypotheses that the elasticity is equal or $>0$ at the $1 \%$ level. Fig. 1 shows that the vast majority of studies appeared in the 1990s, though more recent studies exist for Europe, which reflects the re-emerging policy relevance of the pesticide demand regulation. Despite the fact that some studies report on particular types of pesticides or even on individual products (e.g. Shumway and Chesser, 1994), the majority of studies present elasticities for pesticides in general so that no patterns can be observed.

Fig. 2 presents the distribution of demand elasticities by continent. European studies (22 studies, 64 observations) dominate over North American studies (nine studies, 30 observations, only USA) in quantity. The median of demand elasticities is lower in the US (-0.20) than in Europe (-0.30). However, the variability within the US studies is larger, with an interquartile range of 0.51 compared to 0.30 for Europe. The null-hypothesis of no differences across continents cannot be rejected.

Fig. 3 presents the distribution of demand elasticities with respect to input flexibility and time horizon assumed in the studies. We find that the majority of studies analyse long-term effects, accounting for various possibilities to adjust the production system and techniques. As expected, the longer-term perspectives result in more elastic pesticide demand estimates $($ median $=-0.39)$ compared to short-term perspectives $($ median $=-$ 0.18). The null-hypothesis of no differences across time horizons is rejected at the $1 \%$ level of significance. 


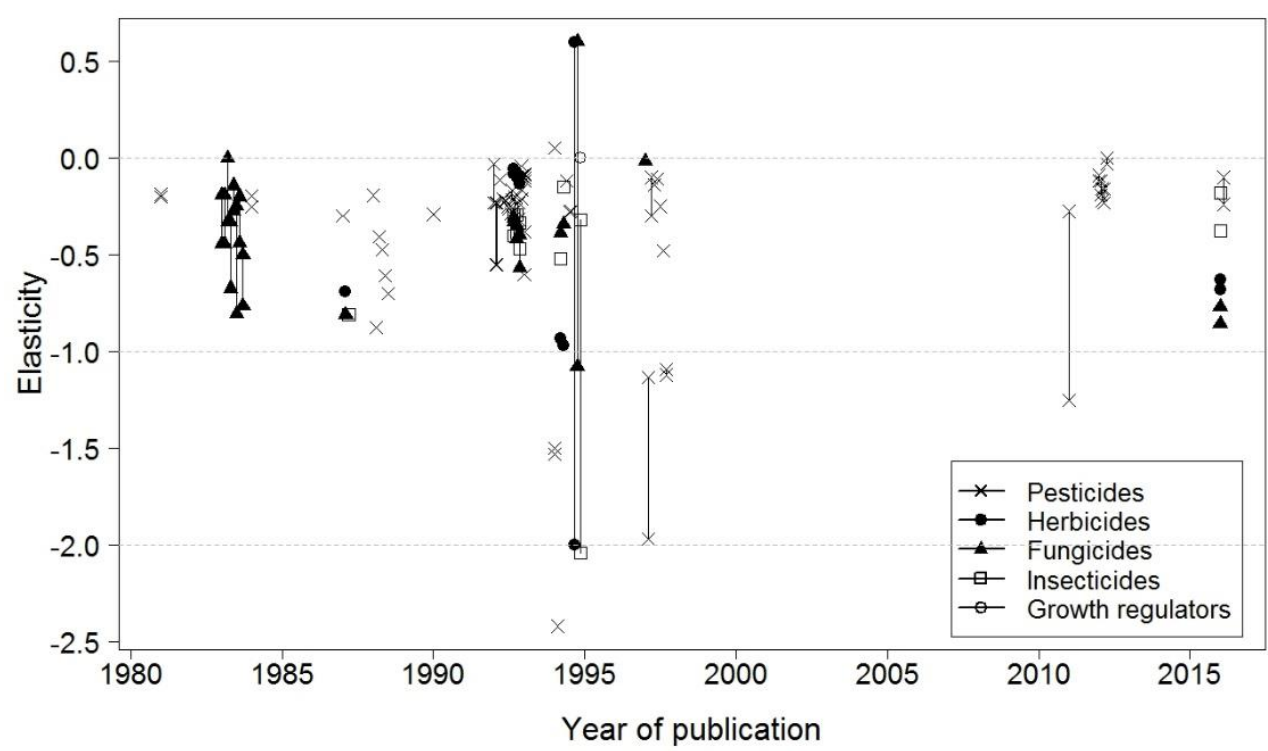

Fig. 1. Pesticide's own-price elasticities of demand following the year of publication.

Note: The lines between two observations refer to an interval because of different elasticity values for different levels of price changes.
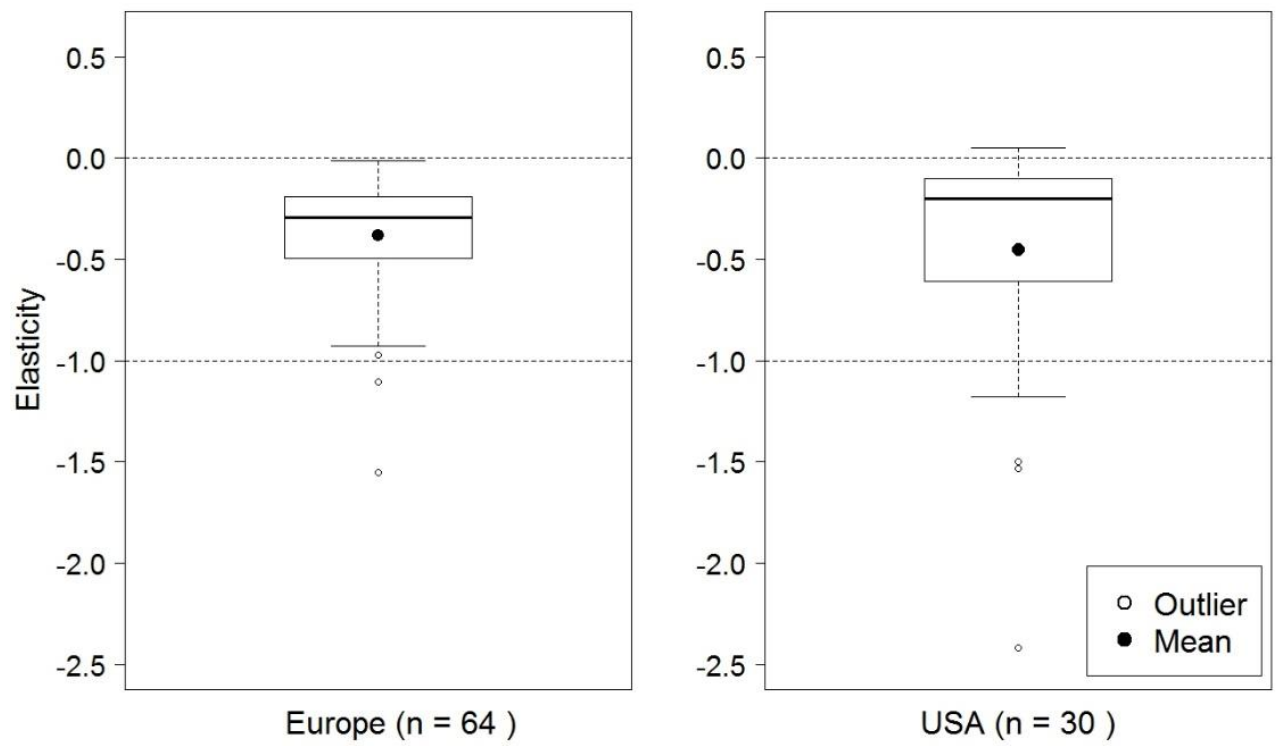

Fig. 2. Pesticide's own-price elasticities of demand for Europe and the USA. 

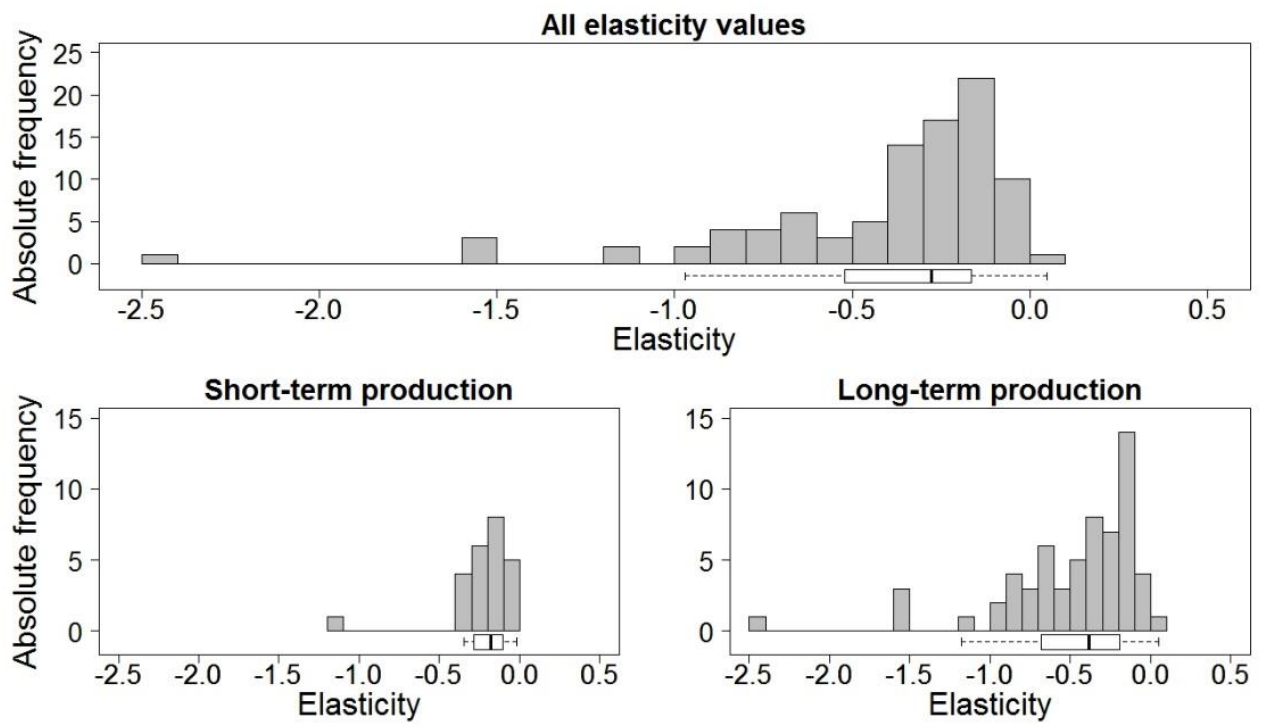

Fig. 3. Pesticide's own-price elasticities of demand arranged by flexibility of production.

Fig. 4 shows demand elasticity estimates by agricultural system investigated. We find that the demand for pesticides in special crops is less elastic (median $=-0.19$ ) than for arable and grassland production (median $=-0.30$ ) and pesticide use in aggregate (e.g. across the entire farm, median $=-0.28$ ). Comparing the demand elasticities in special crops with arable and grassland production, we reject the null-hypothesis of equal demand elasticities at the $5 \%$ level of significance. Moreover, a significant difference can also be found between the aggregate use and special crops ( $5 \%$ level), but not between aggregate use and arable production.

Concerning the analysis of the methodologies underlying pesticide demand elasticity estimation, we find 38 observations for econometric approaches $($ median $=-0.30)$ and 39 observations for normative approaches (median $=-0.21$ ). There is a tendency towards lower elasticities in normative approaches with a significance level of 5\%. Regarding the publication channel, we find that demand elasticities reported in peer-reviewed studies indicate on average a less elastic pesticide demand (33 observations, median $=-0.21$ ) compared to non-peer-reviewed publications (61 observations, median $=-0.29$ ). However, this difference is not significant using a Wilcoxon-Mann-Whitney test. 

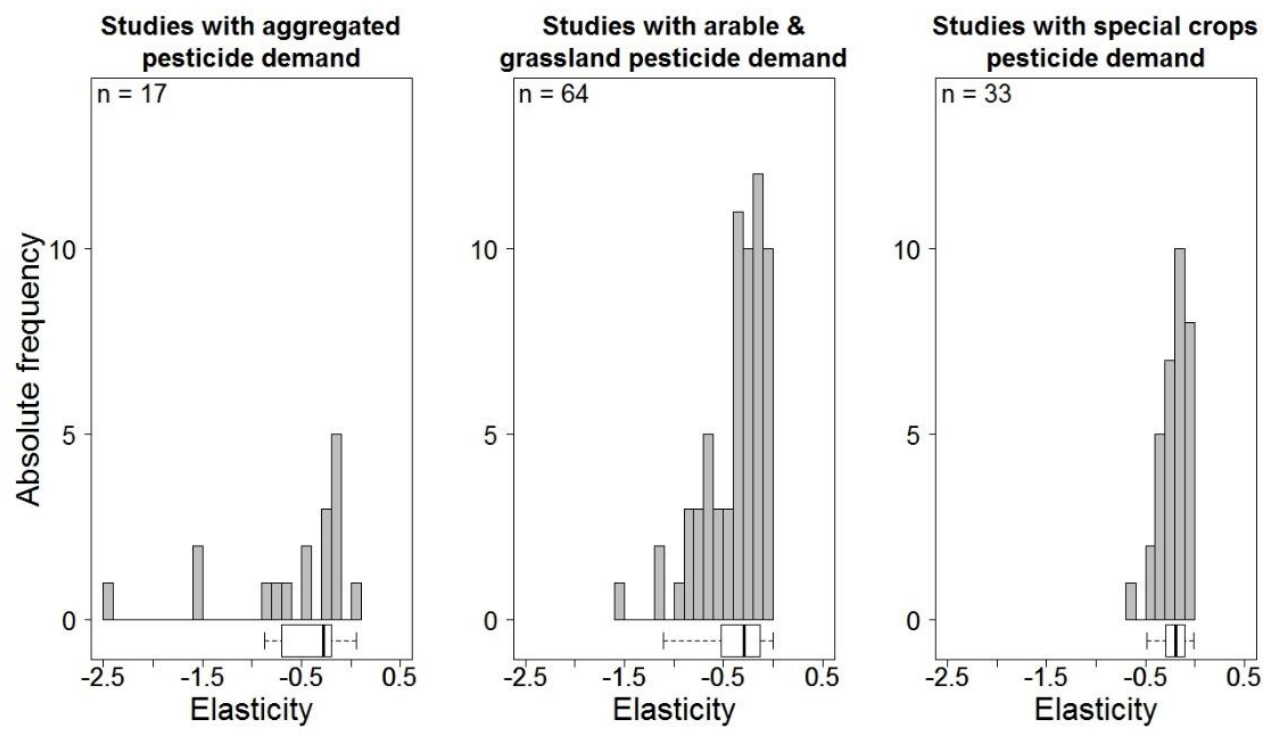

Fig. 4. Subject of analysis in studies estimating pesticide's own-price elasticities of demand.

Finally, we conducted the regression analysis including all of these factors. We find that the explanatory variables 'middle year of the analysis period' and 'peer-review' are not independent of each other. More specifically, peer-reviewed studies are more often observed to be more recent studies with more recent middle years of the analysis. Thus, we present both models with either the middle year of analysis or a dummy for peerreview being included. In addition, the consideration of the methodology used (dummy Econometric analysis) results in several missing observations. As sensitivity analysis, we therefore estimate our models with and without the consideration of this variable. Coefficient estimates of the four models are presented in Table 2. We find pesticide demand to be less elastic when published in peer-reviewed journals. Along these lines, we also find evidence that studies analysing more recent data obtain significantly inelastic demand. Note that the intercepts in Model 1 and 3 refer to the year 1900. Moreover, studies considering a long-term horizon result in more elastic demand elasticity estimates. We find the demand for pesticides in special crops to be less elastic compared to other agricultural sectors, and demand for herbicides is more elastic than for other pesticides. European studies tend to result in more elastic demand estimates, though significance 
tests are ambiguous. Even though econometric studies tend to result in less elastic demand elasticity estimates, we do not find a significant effect of the methodology used. ${ }^{7}$

Table 2. Parameter estimates of the regression models (marginal values)

\begin{tabular}{lcccc}
\hline Parameter & Model 1 & Model 2 & Model 3 & Model 4 \\
\hline $\boldsymbol{\beta}_{0}$ (intercept) & -0.627 & -0.216 & -0.420 & -0.201 \\
& $(-11.016)^{* * *}$ & $(-5.068)^{* * *}$ & $(-2.381)^{* *}$ & $(-4.819)^{* * *}$ \\
\hline $\boldsymbol{\beta}_{1}$ (middle year of & 0.007 & - & 0.004 & - \\
analysis) & $(12.241)^{* * *}$ & & $(1.738)^{*}$ & \\
\hline $\boldsymbol{\beta}_{2}$ (long-term) & -0.173 & 0.212 & -0.177 & -0.215 \\
\hline $\boldsymbol{\beta}_{3}$ (special crops) & $(-5.610)^{* * *}$ & $(-7.232)^{* * *}$ & $(-5.198)^{* * *}$ & $(-7.743)^{* * *}$ \\
\hline $\boldsymbol{\beta}_{4}$ (herbicides) & 0.106 & 0.119 & 0.086 & 0.108 \\
& $(2.279)^{* *}$ & $(3.316)^{* * *}$ & $(1.789)^{*}$ & $(4.022)^{* * *}$ \\
\hline $\boldsymbol{\beta}_{5}$ (Europe) & -0.416 & -0.406 & -0.262 & -0.308 \\
& $(-7.555)^{* * *}$ & $(-5.906)^{* * *}$ & $(-1.955)^{*}$ & $(-3.179)^{* * *}$ \\
\hline $\boldsymbol{\beta}_{6}$ (peer-review) & -0.207 & -0.044 & -0.200 & -0.058 \\
\hline $\boldsymbol{\beta}_{7}$ (econometric & $(-4.854)^{* * *}$ & $(-1.146)(\mathrm{n} . \mathrm{s})$. & $(-2.693)^{* * *}$ & $(-1.495)(\mathrm{n} . \mathrm{s})$. \\
\hline method) & - & 0.184 & - & 0.194 \\
\hline $\begin{array}{l}\text { Degrees of } \\
\text { freedom }\end{array}$ & $(1.587)(\mathrm{n} . \mathrm{s})$. & $(0.979)(\mathrm{n} . \mathrm{s})$. & & $(5.029)^{* * *}$ \\
\hline
\end{tabular}

Notes: Values in parentheses are z-values. n.s. denotes not significant. ${ }^{*}, * *$ and $* * *$ denote significance at the $10 \%, 5 \%$ and $1 \%$, level, respectively. The package 'MASS' was used for MM-estimation. The package 'multiwayvcov' was used for the derivation of the cluster-adjusted standard errors. The R-code for the regressions can be found in Appendix D.

Note that the few studies that report the uncertainty attached to pesticide demand elasticity estimates (e.g. as standard deviation) often report large levels of variability of these estimates (see Appendix C). Besides the considerable degree of across studyheterogeneity, there is also large within-study heterogeneity. Thus, generalising from point estimates needs careful reflection and highlights the importance of analysing different pesticide types and products or different areas of application.

\footnotetext{
${ }^{7}$ As there might be a bias towards econometric analyses among peer-reviewed studies, we estimated the model without the dummy for either peer-review or econometric studies, but find no change in coefficient estimates or levels of significance.
} 


\section{Discussion and Conclusions}

Our meta-analysis reveals that own-price elasticities of demand for pesticides are, with a median of -0.28 , significantly smaller than zero, but also to be significantly larger than 1, i.e. are inelastic. Moreover, demand elasticity estimates are found to be highly heterogeneous across different studies, ranging from complete inelasticity to relatively high elasticity, reflecting the fact that various parameters affect pesticide application. Other developments, such as the development of new pesticides or the occurrence of new pests might even be more important than price developments. For example, Vijftigschild and Oskam (1994) show for the Netherlands that between 1980/81 and 1991/92, despite pesticide prices increased up to $32.5 \%$, the pesticide demand increased by $20 \%$, which would indicate a simple and crude elasticity of +0.63 . In a similar vein, pesticides taxes have not necessarily led to sharp decreases in pesticide use, as observed in Sweden and Denmark under the former tax scheme, but, rather, to a substitution of products, as observed in Norway (Böcker and Finger, 2016).

Nevertheless, our results show that demand elasticities are significantly smaller than zero so that, ceteris paribus, there will be a quantity reduction if pesticide prices are increased. This indicates that taxation of pesticides will have an effect of reducing pesticide use. However, the finding of inelastic demand for pesticides also indicates that large levels of taxation are required to realise substantial quantity reductions. The metaanalysis also identifies specific agricultural production environments, where the elasticity of the demand for pesticides is almost zero (e.g. Skevas et al., 2012), and where the effectiveness of taxation will be limited. This finding highlights the importance of country-specific ex-ante analyses of policy measures. Our meta-analysis reveals a large heterogeneity of the magnitude of these effects. More specifically, we find that price elasticities of demand are more inelastic in special crops (horticulture, fruit production and viticulture) compared to arable and grassland farming. This is especially relevant since special crops usually need the largest amount of pesticides per hectare - particularly more fungicide and insecticide but less herbicide. The lower elasticity can be explained due to the fact that (i) fruit production and viticulture are spatially less flexible in production than other crops, (ii) the harvest is more valuable and quality aspects are more 
important (e.g. Weston and Barth, 1997), (iii) pesticides are applied more often preventively, and (iv) fewer substitutes exist for those sectors. This finding also highlights that a pesticide tax could imply non-uniform income effects on farms, e.g. comparing farmers growing special crops and arable farmers. Our results show that herbicide demand is more elastic than fungicides and insecticides. Thus, taxation might be particularly suited to reducing herbicide use. Next to the heterogeneity across crops and pesticide type, also a considerable heterogeneity of demand elasticities across time was revealed in our analysis. In the short-run, the median demand elasticities are significantly less elastic than in the long-run, which is in line with Le Chatelier's principle generalised by Samuelson (1983). We find that estimated demand elasticities significantly decreased over time (middle year of the analysis period) and with peer-review. Even though it is not possible in our analysis to identify causalities and determinants for this development, the finding is in line with qualitative observations made in Skevas et al. (2012) and Fadhuile et al. (2016). Skevas et al. (2012) argue that demand elasticities are lower due to increasing importance of pesticides in current agricultural production practices in comparison to earlier decades. Fadhuile et al. (2016) argue that stricter policies result in smaller numbers of available pesticides, i.e. a decreasing number of substitutes, which leads to more inelastic demand. Thus, in these situations, pesticide taxes may have a limited effectiveness. However, pesticide taxes may also promote changed behaviour towards more agronomical, biological or mechanical plant protection measures.

Despite the fact that policy-makers often aim to reduce the use of toxic pesticides and not necessarily the quantity of all aggregated pesticides, little information about demand differences with respect to the toxicity of the pesticides was found in our research: only Skevas et al. (2012) show that the demand elasticity is smaller for more toxic pesticides ( -0.0003 vs. -0.03 for less toxic ones). Future research should focus on this aspect, because for policy implications, it motivates a taxation approach that accounts for the toxicity of different pesticide products, as implemented in Norway, Denmark and France. 


\section{Acknowledgements}

The authors would like to thank the two anonymous referees and the Editor for constructive comments and suggestions on an earlier version of this paper. Moreover, the authors thank the Swiss Federal Office for Agriculture for funding and supporting this research.

\section{Appendix}

Additional Supporting Information may be found in the online version of this article: https://doi.org/10.1111/1477-9552.12198.

\section{Appendix A:}

\section{Additional notes to the selection of studies}

More studies were found which simulate price increases on pesticides, but elasticities could not be derived, because the pre-tax costs are unknown (e.g. by a tax: Archer and Shogren (2001) simulate different tax systems). Dubberke and Schmitz (1993) report a price elasticity of -0.777 , which however is not significant at the $10 \%$ level. Moreover, Zeddies et al. (1992) simulate for winter wheat in Germany that a relative price increase of 1.5 would lead to zero pesticide use. However, the results are criticised by themselves as not realistic in practice. During the literature analysis, also some studies outside the North America and Europe were found giving examples for pesticide elasticities (e.g. the analyses of Antle and Pingali (1994) and of Tjornhom et al., 1998 for the Philippines). Those studies are not included.

In comparison to other studies, we have not included the following publications: We were not able to find any (original) information about price elasticities of demand in Lichtenberg et al. (1988), Pettersson et al. (1989) and Carpentier (1994) and thus excluded them from the analysis. The studies of Hazilla and Kopp from 1986, Johnsson from 1991, and ECOTEC from 1997 were not found in the literature search. The preliminary study of the Dutch DHV and LUW from 1991 was replaced by Oskam et al. (1992). The latter is included in the analysis. 
Appendix B:

Data collected from studies as CSV-file (Online)

\section{Appendix C:}

Table with studies reporting a standard deviation of elasticity results

Table A1. Studies reporting a standard deviation of elasticity results

\begin{tabular}{lrcc}
\hline Author & Elasticity & \multicolumn{1}{l}{ SD } & SD/Elasticity \\
\hline Antle (1984) & -0.194 & 0.354 & -1.82 \\
Antle (1984) & -0.254 & 0.204 & -0.80 \\
McIntosh and Williams (1992) & -0.112 & 0.034 & -0.30 \\
Oskam et al. (1992) & -0.210 & 0.150 & -0.71 \\
Oskam et al. (1992) & -0.220 & 0.150 & -0.68 \\
Oskam et al. (1992) & -0.220 & 0.150 & -0.68 \\
Oskam et al. (1992) & -0.250 & 0.190 & -0.76 \\
Oskam et al. (1992) & -0.260 & 0.190 & -0.73 \\
Oskam et al. (1992) & -0.290 & 0.190 & -0.66 \\
Oude Lansink (1994) & -0.120 & 0.080 & -0.67 \\
Papanagiotou et al. (1994) & -0.279 & 0.163 & -0.58 \\
Papanagiotou et al. (1994) & -0.276 & 0.157 & -0.57 \\
Fadhuile et al. (2016) & -0.629 & 0.027 & -0.04 \\
Fadhuile et al. (2016) & -0.856 & 0.009 & -0.01 \\
Fadhuile et al. (2016) & -0.374 & 0.025 & -0.07 \\
Fadhuile et al. (2016) & -0.681 & 0.029 & -0.04 \\
Fadhuile et al. (2016) & -0.769 & 0.009 & -0.01 \\
Fadhuile et al. (2016) & -0.182 & 0.033 & -0.18 \\
\hline
\end{tabular}




\section{Appendix D:}

\section{$R$ code for the regression analysis}

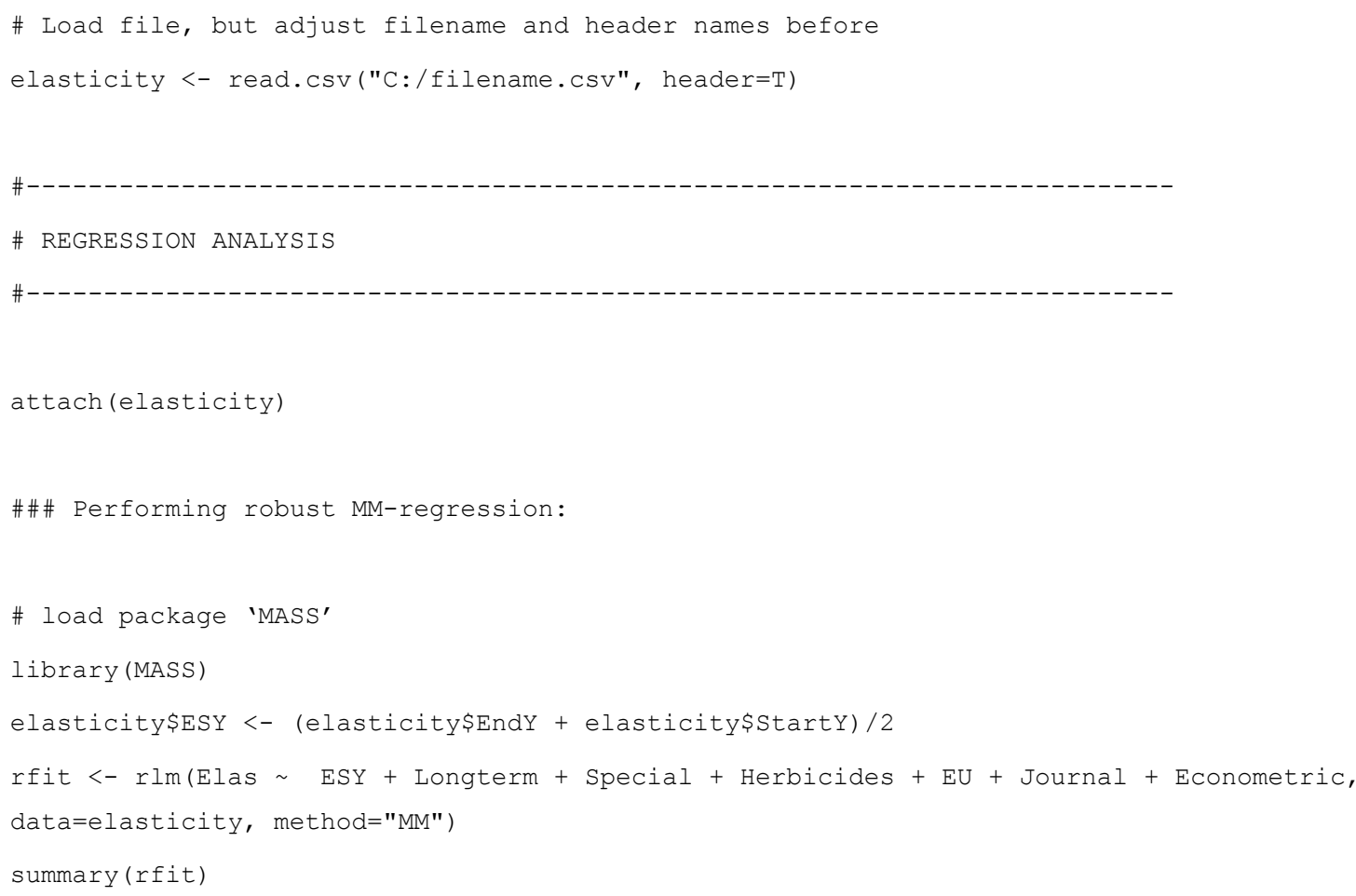




\section{References}

Antle, J. M. (1984). The structure of US agricultural technology, 1910-78. American Journal of Agricultural Economics 66 (4): 414-421.

Antle, J. M. and Pingali, P. L. (1994). Pesticides, Productivity, and Farmer Health: A Philippine Case Study. American Journal of Agricultural Economics 76 (3): 418-430.

ARCADIS Belgium (ed.) (2014). Vergroening van de fiscaliteit. Bijlage 2: Groslijst vergroeningsopties. Version 4/2014, Working paper BE0114000073. Brussels: ARCADIS Belgium nv/sa.

Archer, D. W. and Shogren, J. F. (2001). Risk-indexed herbicide taxes to reduce ground and surface water pollution: an integrated ecological economics evaluation. Ecological Economics 38 (2): 227-250.

Bauer, S., Hoppe, U. and Hummelsheim, S. (1997). Decision support system for controlling pesticide use in Hessen. In Oskam, A. J. and Vijftigschild, R. A. N. (eds), Proceedings and discussions, Workshop on pesticides, Wageningen, August 24th-27th, 1995. Wageningen: Wageningen Agricultural University, 293-312.

Bergh, J. C. J. M. van den, Button, K. J., Nijkamp, P. and Pepping, G. C. (1997). Effectiveness of pesticide price policies in agriculture. In van den Bergh, J. C. J. M., Button, K. J., Nijkamp, P. and Pepping, G. C. (eds), Meta-Analysis in Environmental Economics. Dordrecht: Springer, 163-174.

Böcker, T. and Finger, R. (2016). European Pesticide Tax Schemes in Comparison: An Analysis of Experiences and Developments. Sustainability 8 (4/378): 1-22.

Brown, R. S. and Christensen, L. R. (1981). Estimating Elasticities of Substitution in a Model of Partial Static Equilibrium: An Application to U.S. Agriculture, 1947 to 1974. In Berndt, E. R. and Field, B. C. (eds), Modeling and measuring natural resource substitution. Cambridge, MA, USA and London: MIT Press, 209-229.

Capalbo, S. M. (1988). A Comparison of Econometric Models of U.S. Agricultural Productivity and Aggregate Technology. In Capalbo, S. M. and Antle, J. M. (eds), Agricultural Productivity - Measurement and Explanation. Waschington, D.C.: Resources for the Future, 159-188.

Capalbo, S. M. and Vo, T. T. (1988). A Review of the Evidence on Agricultural Productivity and Aggregate Technology. In: Capalbo, S. M. and Antle, J. M. (eds), Agricultural Productivity - Measurement and Explanation. Washington, D.C.: Resources for the Future, 96-137.

Carpentier, A. (1994). A pesticide ban in the context of intensive cropping technology: the case of the French crop sector. In Michalek, J. and Hanf, C.-H. (eds), The economic consequences of a drastic reduction in pesticide use in the EU, Revised papers of a workshop held in Tannenfelde (Schleswig-Holstein) November 13th-14th, 1993. Kiel: Wissenschaftsverlag Vauk Kiel KG, 281-306. 
Carpentier, A. and Weaver, R. D. (1997). Damage Control Productivity: Why Econometrics Matters. American Journal of Agricultural Economics 79 (1): 47-61.

Chambers, R. G. and Lichtenberg, E. (1994). Simple Econometrics of Pesticide Productivity. American Journal of Agricultural Economics 76 (3): 407-417.

Chen, P. C., McIntosh, C. S. and Epperson, J. E. (1994). The Effects of a Pesticide Tax on Agricultural Production and Profits. Journal of Agribusiness 12 (2): 125-138.

Dubberke, H. and Schmitz, P. M. (1993). Ökometrische Schätzung von Elastizitäten. In Schmitz, P. M. and Hartmann, M. (eds), Landwirtschaft und Chemie. Kiel: Wissenschaftsverlag Vauk Kiel KG, 169-189.

Dubgaard, A. (1987). Anvendelse af afgifter til regulering af pesticidforbruget. Rapport nr. 35, Copenhagen: Statens Jordbrugsøkonomiske Institut.

Dubgaard, A. (1991). Pesticide Regulation in Denmark. In Hanley, N. (ed.), Farming and the Countryside: An Economic Analysis of External Costs and Benefits. Wallingford, UK: C.A.B International, 48-58.

Elhorst, J. P. (1990). De inkomensvorming en de inkomensverdeling in de Nederlandse landbouw verklaard vanuit de huishoudproduktietheorie. Dissertation. The Hague: LandbouwEconomisch Instituut.

Fadhuile, A., Lemarié, S. and Pirotte, A. (2016). Disaggregating the Demand for Pesticides: Does it Matter? Canadian Journal of Agricultural Economics 64 (2): 223-252.

Falconer, K. E. (1998). Managing diffuse environmental contamination from agricultural pesticides: an economic perspective on issues and policy options, with particular reference to Europe. Agriculture, Ecosystems and Environment 69 (1): 37-54.

Falconer, K. E. and Hodge, I. (2000). Using economic incentives for pesticide usage reductions: responsiveness to input taxation and agricultural systems. Agricultural systems 63 (3): 175194.

Femenia, F. and Letort, E. (2016). How to significantly reduce pesticide use: An empirical evaluation of the impacts of pesticide taxation associated with a change in cropping practice. Ecological Economics 125: 27-37.

Fernandez-Cornejo, J. (1993). Demand and Substitution of Agricultural Inputs in the Central Corn Belt States. Technical Bulletin No. 1816. Washington, D.C.: U. S. Department of Agriculture - Economic Research Service.

Fernandez-Cornejo, J., Sharon, J. and Smith, M. (1998). Issues in the economics of pesticide use in agriculture: a review of the empirical evidence. Review of Agricultural Economics 20 (2): $462-488$.

Finger, R. (2010). Revisiting the Evaluation of Robust Regression Techniques for Crop Yield Data Detrending. American Journal of Agricultural Economics 92 (1): 205-211.

Filippini, M. (2011). Short-and long-run time-of-use price elasticities in Swiss residential electricity demand. Energy Policy 39 (10): 5811-5817. 
Gren, I.-M. (1994a). Cost Efficient Pesticide Reductions: A study of Sweden. Environmental and Resource Economics 4: 279-293.

Gren, I.-M. (1994b). Regulating the Farmers' use of Pesticides in Sweden. In Opschoor, H. and Turner, K. (eds), Economic Incentives and Environmental Policies - Principles and Practice. Dordrecht: Kluwer Academic Publishers, 153-173.

Hoevenagel, R., van Noort, E. and de Kok, R. (1999). Study on a European Union wide regulatory framework for levies on pesticides. Zoetermeer: EIM Small Business Research and Consultancy/Haskoning.

Hof, B., Koopmans, C., Rougoor, W. and van der Voort, J. (2013). Effecten en vormgeving van een heffing op gewasbeschermingsmiddelen. Rapport nr. 2013-39. Amsterdam: seo economisch onderzoek.

Ivanova, N., Stoyanova, Z. and Mishev, P. (2012). Estimation of Optimal Tax Level on Pesticides Use and its Impact on Agriculture. Bulgarian Journal of Agricultural Science 18 (5): 641 650 .

Jacquet, F., Butault, J.-P. and Guichard, L. (2011). An economic analysis of the possibility of reducing pesticides in French field crops. Ecological Economics 70 (9): 1638-1648.

Komen, M. H. C., Oskam, A. J. and Peerlings, J. (1997). Effects of reduced pesticide application for the Dutch economy. In Oskam, A. J. and Vijftigschild, R. A. N. (eds), Proceedings and discussions, Workshop on pesticides, Wageningen, August 24th-27th, 1995. Wageningen: Wageningen Agricultural University, 344-359.

Lefebvre, M., Langrell, S. R. H. and Gomez-y-Paloma, S. (2015). Incentives and policies for integrated pest management in Europe: a review. Agronomy for Sustainable Development 35 (1): $27-45$.

Lichtenberg, E., Parker, D. D. and Zilberman, D. (1988). Marginal Analysis of Welfare Costs of Environmental Policies: The Case of Pesticide Regulation. American Journal of Agricultural Economics 70 (4): 867-874.

McIntosh, C. S. and Williams A. A. (1992). Multiproduct production choices and pesticide regulation in Georgia. Southern Journal of Agricultural Economics 24 (1): 135-144.

Möckel, S., Gawel, E., Bretschneider W. Kästner, M., Liess, M. and Knillmann, S. (2015a). Eine Abgabe auf Pflanzenschutzmittel für Deutschland. Natur und Recht 37 (10) 669-677.

Möckel, S., Gawel, E., Kästner, M., Liess, M., Knillmann, S. and Bretschneider W. (2015b). Einführung einer Abgabe auf Pflanzenschutzmittel in Deutschland. In Gawel, E. (ed.), Studien zu Umweltökonomie und Umweltpolitik. Vol. 10. Berlin: Duncker \& Humblot, 1305.

Muñoz Piña, C. and Avila Forcada, S. (2004). Effects of an environmental tax on pesticides in Mexico. Industry and Environment 27 (2), 33-36.

Oskam, A. J., van Zeijts, H., Thijssen, G. J., Wossink, G. A. A. and Vijftigschild, R. (1992). Pesticide use and pesticide policy in the Netherlands. Wageningen: Wageningen Agriculture University. 
Oude Lansink, A. G. J. M. (1994). Effects of input quotas in Dutch arable farming. Tijdschrift voor sociaalwetenschappelijk oderzoek van de Landbouw 9 (3): 197-217.

Oude Lansink, A. G. J. M. and Peerlings, J. H. M. (1997). Farm-specific impacts of policy changes on pesticide use in Dutch arable farming. In Oskam, A. J. and Vijftigschild, R. A. N. (eds), Proceedings and discussions, Workshop on pesticides, Wageningen, August 24th27th, 1995. Wageningen: Wageningen Agricultural University, 414-428.

Papanagiotou, E., Alexandridis, K. and Melfou, K. (1994). Some implications of pesticide ban policies in Greece. In Michalek, J. and Hanf, C.-H. (eds), The economic consequences of a drastic reduction in pesticide use in the EU, Revised papers of a workshop held in Tannenfelde (Schleswig-Holstein) November 13th-14th, 1993. Kiel: Wissenschaftsverlag Vauk Kiel KG, 307-317.

Pettersson, O., Pettersson, J., Johansson, V., Fogelfors, H., Sigvald, R. and Johnsson, B. (1989). Minskad kemisk bekämpning i jordbruket: möjligheter och konsekvenser. Journal of the Royal Swedish Academy of Agriculture and Forestry 128 (4-5): 379-396.

R Core Team (2015). R: A language and environment for statistical computing. R Foundation for Statistical Computing. R Core Team: Vienna. Online: https://www.R-project.org/.

Rude, S. (1992). Pesticidforbrugets udvikling - landbrugs- og miljøpolitiske scenarier. Rapport nr. 68. Copenhagen: Statens Jordbrugsøkonomiske Institut.

Russel, N. P., Smith, V. H. and Goodwin, B. K. (1997). The Effects of CAP Reform on the Demand for Crop Protection in the U.K. In Oskam, A. J. and Vijftigschild, R. A. N. (eds), Proceedings and discussions, Workshop on pesticides, Wageningen, August 24th-27th, 1995. Wageningen: Wageningen Agricultural University, 397-413.

Samuelson, P. A. (1983). Foundations of Economic Analysis. Enlarged Ed. Cambridge, MA, and London: Harvard University Press.

Schulte, J. (1983). Der Einfluß eines begrenzten Handelsdünger- und Pflanzenbehandlungsmitteleinsatzes auf Betriebsorganisation und Einkommen verschiedener Betriebssysteme. Dissertation. Bonn: Rheinische Friedrich-WilhelmsUniversität Bonn - Faculty of Agriculture.

Shumway, C. R. and Chesser, R. R. (1994). Pesticide Tax, Cropping Patterns, and Water Quality in South Central Texas. Journal of Agricultural and Applied Economics 26 (1): 224-240.

Skevas, T., Oude Lansink, A. G. J. M. and Stefanou, S. E. (2013). Designing the emerging EU pesticide policy: A literature review. NJAS - Wageningen Journal of Life Sciences 64-65: 95-103.

Skevas, T., Stefanou, S. E. and Oude Lansink, A. (2012). Can economic incentives encourage actual reductions in pesticide use and environmental spillovers? Agricultural Economics 43 (3): 267-276.

Tjornhom, J. D., Norton, G. W. and Gapud, V. (1998). Impacts of price and exchange rate policies on pesticide use in the Philippines. Agricultural Economics 18 (2): 167-175. 
Vijftigschild, R. A. N. and Oskam, A. J. 'Pesticide use in the Netherlands: extent, problems and policy. In Michalek, J. and Hanf, C.-H. (eds), The economic consequences of a drastic reduction in pesticide use in the EU, Revised papers of a workshop held in Tannenfelde (Schleswig-Holstein) November 13th-14th, 1993. Kiel: Wissenschaftsverlag Vauk Kiel KG, 135-171.

Villezca-Becerra, P. A. and Shumway, C. R. (1992). State-Level Output Supply and Input Demand Elasticities for Agricultural Commodities. Journal of Agricultural Economics Research 44 (1): 22-34.

Weston, L.A. and Barth, M.M. (1997). Preharvest Factors Affecting Postharvest Quality of Vegetables. HortScience 32 (5): 812-816.

Zeddies, J., Fuchs, C. and Schanzenbacher, B. (1992). Marktwirkungen von Öko-Steuern und EG-Agrarreform. In Agrarsoziale Gesellschaft e.V. (ed.), Schriftenreihe für ländliche Sozialfragen: Öko-Steuern als Ausweg aus der Agrarkrise? Ergebnisse der internationalen Tagung vom 15. Bis 17. Juni 1992 in Stuttgart-Hohenheim. Göttingen: Agrarsoziale Gesellschaft e.V., 137-149. 